\title{
Studi Literatur Pengaruh Pirolisis, Jenis Adsorban serta Aktivator dalam Karakterisasi Asap Cair
}

\section{Rony Pasonang Sihombing, Keryanti, Fitria Yulistiani, Ayu Ratna Permanasari*}

Politeknik Negeri Bandung, Bandung, 40559, Indonesia

\begin{tabular}{l} 
I N F O A R T I K E L \\
\hline Diterima 23 Januari 2021 \\
Disetujui 30 April 2021 \\
\\
\hline Keyword: \\
liquid smoke \\
pyrolisys \\
adsorbant \\
activator \\
\hline Kata kunci: \\
asap cair \\
pirolisis \\
adsorban \\
aktivator
\end{tabular}

*e-mail: ayu.ratna@polban.ac.id

\begin{abstract}
A B S T R A C T
Liquid smoke is a preservative solution that can be used safely. This grade 1 product can also be used as a food preservative. This article aims to discuss and examine the previous experiment's results by literature review. The outcome of this article is expected to be regenerated by other research using the existing variable discussed in this article or using a new variable. Based on the result. Some variables affect the final quality of liquid smoke. Some of them are pyrolysis temperature, pyrolysis time, adsorbent type, and activator type. Pyrolysis temperature used was around $250{ }^{\circ} \mathrm{C}-$ $300{ }^{\circ} \mathrm{C}$ with resulted $\mathrm{pH} 1.41$ to 2.25 . While for pyrolysis, the temperature was around 4-5 hours with phenol content around 3.04\% to $4.08 \%$. The type of adsorbent used was zeolite and quartz sand, in which the acid total was having both increment and decrement phenomena. Activator types used were salt activators such as $\mathrm{NaCl}, \mathrm{NaHCO}, \mathrm{CaCl} 2, \mathrm{Na} 2 \mathrm{SO} 4$ and base activator (NaOH), producing the most percent acid total.
\end{abstract}

A B S T R A K

Asap cair merupakan solusi pengawet yang dapat digunakan dengan aman. Produk asap cair kualitas grade 1 dapat digunakan sebagai pengawet makanan. Penelitian ini bertujuan untuk membahas hasil dari penelitianpenelitian sebelumnya secara studi literatur. Hasil studi literatur ini diharapkan dapat disempurnakan dengan penelitian lanjut menggunakan variabel-variabel yang dibahas dalam artikel ini maupun dengan menggunakan variabel baru. Berdasarkan hasil studi literatur ada beberapa variabel yang cukup berpengaruh pada kualitas akhir dari sebuah asap cair. Diantaranya adalah suhu pirolisis, waktu pirolisis, jenis adsorban dan jenis aktivator. Suhu pirolisis yang digunakan sekitar $250{ }^{\circ} \mathrm{C}-300{ }^{\circ} \mathrm{C}$ dengan hasil pH 1.41 hingga 2.25. Untuk lama waktu pirolisis berkisar 4 - 5 jam dengan hasil kandungan fenol $3.04 \%-4.08 \%$. Sedangkan untuk jenis adsorban yang digunakan adalah zeolit dan pasir kuarsa, yang menghasilkan fenomena peningkatan dan penurunan total asam. Jenis aktivator yang digunakan adalah jenis aktivator garam seperti $\mathrm{NaCl}, \mathrm{NaHCO}, \mathrm{CaCl}_{2}, \mathrm{Na}_{2} \mathrm{SO}_{4}$ dan aktivator basa $(\mathrm{NaOH})$ dimana aktivator basa menghasilkan persen total asam terbanyak.

\section{Pendahuluan}

Tersebarnya makanan dengan pengawet formalin meningkatkan kecemasan dari pihak masyarakat. Beberapa alasan mengapa formalin digunakan sebagai pengawet produk makanan antara lain adalah karena harganya yang relatif murah dan penggunaannya yang mudah. Permasalahan yang muncul saat ini adalah terkait alasan keamanan bagi tubuh.
Kondisi ini membutuhkan solusi lain dari penggunaan formalin sehingga asap cair diperkenalkan. Banyak hal yang berpengaruh pada sintesis asap cair adalah komposisi kayu (sebagai bahan baku) dan suhu pirolisis (sebagai metode sintesis) [1] dan lemak bahan [2].

Sintesis asap cair dapat dilakukan dengan memanfaatkan beberapa bahan baku. 
Diantaranya adalah dari bahan kelapa [3-5]. Beberapa berbahan jagung [5-7] dan beberapa menggunakan sawit [8]. Selanjutnya menggunakan bahan durian [9].

Asap cair merupakan bahan kimia yang merupakan hasil destilasi asap hasil pembakaran. Di dalam material ini, terkandung beberapa bahan kimia yang dapat digunakan sebagai zat antioksidan, pengawet, desinfektan, biopestisida [10]. Dalam proses pembuatannya, asap cair ini dapat dibagi menjadi beberapa grade. Grade pertama yang bisa dicapai adalah grade 3 , dimana asap cair grade 3 dapat dimanfaatkan sebagai bahan anti bakteri dan anti oksidan. Biasanya jenis asap cair grade 3 ini digunakan dalam pengawetan kayu, anti jamur, anti rayap [6].

Kemudian ada asap cair grade 2 yang dapat dimanfaatkan sebagai pengawet makanan dan digunakan sebagai pengganti formalin dengan taste asap (lemah), sedikit rasa asam dan berwarna coklat transparan. Sedangkan asap cair grade 1 digunakan sebagai pengawet makanan. Material ini berwarna bening, sedikit asam, beraroma netral dan tidak mengandung senyawasenyawa berbahaya. Asap cair ini dapat digunakan dikarenakan adanya senyawa asam, fenolat dan karbonil yang berperan dalam pengawetan bahan makanan.

Selain dari asal bahan baku, pembuatan asap cair ini dapat juga dilihat dari jenis bahan adsorbent nya. Secara umum, bahan aktif yang digunakan untuk pemurnian adalah zeolit dan arang. Namun pada beberapa jurnal lain, pasir kuarsa dapat digunakan untuk pemurnian [11].

\section{Pengaruh jenis adsorban terhadap kandungan asam pada asap cair.}

Pada aplikasinya, kandungan asam pada asap cair dapat dimanfaatkan sebagai anti mikroba dalam kurun waktu tertentu.

Pada penelitian sebelumnya,adsorban yang digunakan adalah jenis pasir kuarsa [11] untuk proses pemurnian. Sedangkan penelitian lain menggunakan zeolit $[9,12]$ Hasil perbandingan dapat dilihat pada Tabel 1.

Dari hasil dalam tabel 1, ada fenomena dimana ada total asam yang mengalami peningkatan, namun juga ada yang mengalami penurunan. Hal ini disebabkan karena struktur dasar adsorban yang mana pasir kuarsa terdiri dari ikatan Si-Si dan zeolit terbentuk dari Si-Al. Pada zeolit, dengan adanya atom $\mathrm{O}$ yang digunakan bersama, akan menyebabkan perbedaan dalam penjeraban ikatan kationik yang salah satunya berasal dari asam. Sehingga setelah pemurnian, ada peningkatan nilai total asam.

Tabel 1. Efek Jenis Adsorban terhadap

Kandungan Asam pada Asap Cair.

\begin{tabular}{lll}
\hline Referensi & Kondisi & Total asam \\
\hline$[9]$ & $\begin{array}{l}\text { Sebelum } \\
\text { pemurnian }\end{array}$ & $7,59 \mathrm{ml} / \mathrm{L}$ \\
& $\begin{array}{l}\text { Setelah } \\
\text { pemurnian }\end{array}$ & $9,11 \mathrm{ml} / \mathrm{L}$ \\
{$[11]$} & $\begin{array}{l}\text { Sebelum } \\
\text { pemurnian }\end{array}$ & $7,69 \%$ \\
& $\begin{array}{l}\text { Setelah } \\
\text { pemurnian } \\
{[12]}\end{array}$ & $6,24 \%$ \\
& $\begin{array}{l}\text { Sebelum } \\
\text { pemurnian } \\
\text { Setelah } \\
\text { pemurnian }\end{array}$ & $44,7 \%$ \\
& & $46,71 \%$ \\
\hline
\end{tabular}

\section{Pengaruh jenis aktivator terhadap kandungan total asam.}

Aktivator merupakan aditif yang cukup penting keberadaannya dalam sebuah pemurnian. Beberapa penelitian menggunakan jenis aktivator yang berbeda untuk aktivasi adsorban yang digunakan. Diantaranya adalah jenis aktivator garam [13] dan basa [11]. Pada aplikasinya, total asam Hasil perbandingan dapat dilihat pada Tabel 2.

Tabel 2. Efek Jenis Aktivator terhadap Total

\begin{tabular}{lc} 
& Asam \\
\hline Jenis aktivator & $\%$ total asam \\
\hline $\mathrm{NaCl}$ & 1.22 \\
$\mathrm{NaHCO}$ & 1.69 \\
$\mathrm{CaCl}_{2}$ & 1.15 \\
$\mathrm{Na}_{2} \mathrm{SO}_{4}$ & 0.97 \\
$\mathrm{NaOH}$ & 6.13 \\
\hline
\end{tabular}

Dalam aplikasi asap cair, kandungan asam dinyatakan dalam asam asetat. Kandungan asam pada asap cair ini digunakan sebagai bahan anti mikroba menghambat pertumbuhan bakteri [14]. 
Pengaruh fenol terhadap kualitas asap cair.

Dalam aplikasi asap cair, kandungan fenol menentukan kualitasnya. Semakin tinggi kandungan fenol, semakin bagus kualitas asap cair yang dihasilkan. Penelitian yang sebelumnya melakukan proses pirolisis dengan suhu $250^{\circ} \mathrm{C}$ selama 4 jam, kemudian dilakukan destilasi dan pemurnian [5]. Sedangkan penelitian lainnya, melakukan proses hidrolisis dengan waktu 5 jam [4]. Hasilnya dapat dilihat pada Tabel 3 sebagai berikut:

Tabel 3. Pengaruh Fenol terhadap Kualitas

\begin{tabular}{lll} 
& Asap Cair \\
\hline $\begin{array}{l}\text { Lama } \\
\text { pirolisis } \\
\text { (jam) }\end{array}$ & $\begin{array}{l}\text { Kandungan } \\
\text { Fenol }(\%)\end{array}$ & $\begin{array}{l}\text { Kandungan } \\
\text { Benzopyrene }\end{array}$ \\
\hline 4 & 3.04 & $\begin{array}{l}\text { Tidak } \\
\text { terdeteksi } \\
\text { Tidak } \\
\text { terdeteksi }\end{array}$ \\
\hline
\end{tabular}

Perusakan dinding bakteri dapat dilakukan oleh fenol dengan pemutusan ikatan peptidogligen [15]. Hal ini mengakibatkan pembentukan lapisan sel tidak terbentuk secara utuh. Senyawa kompleks protein dapat terbentuk dari senyawa fenol dan turunannya dengan adanya ikatan hidrogen [16]. Pada kadar rendah, terjadi denaturasi pada dinding sel bakteri karena terbentuknya kompleks protein-fenol dengan ikatan lemah. Hal ini mengakibatkan penguraian dalam dinding sel bakteri [17]. Pada kadar tinggi, senyawa fenol mengakibatkan sel bakteri mengalami lisis [18].

Benzopyrene merupakan salah satu senyawa PAH (Polisiklik Aromatik Hydrocarbon) yang berbahaya bagi kesehatan. Dengan tidak terdeteksinya senyawa tersebut, maka kualitas asap cair yang dihasilkan dapat digunakan untuk food application.

\section{Pengaruh $\mathrm{pH}$ terhadap kualitas asap cair.}

Menurut penelitian sebelumnya, suhu dan waktu pirolisis memberikan kontibusi terhadap hasil $\mathrm{pH}$ produk. Penelitian tersebut antara lain disajikan pada Tabel 4.

$\mathrm{pH}$ digunakan untuk standarisasi kualitas asap cair. Sebagai contoh, di negara Jepang menetapkan nilai $\mathrm{pH}$ untuk cuka kayu berkisar antara 1.5 - 3.7 [3]. Semakin rendah nilai $\mathrm{pH}$, semakin baik kualitas asap cair yang dihasilkan. Hal ini dikarenakan akan berpengaruh terhadap masa simpan produk asap cair tersebut.

Tabel 4. Pengaruh $\mathrm{pH}$ terhadap Kualitas Asap Cair.

\begin{tabular}{llll}
\hline referensi & $\begin{array}{l}\text { Pirolisis } \\
\text { (Suhu, } \\
\text { waktu) }\end{array}$ & hH & hasil \\
\hline$[3]$ & $\begin{array}{l}300{ }^{\circ} \mathrm{C}, 5 \\
\text { jam }\end{array}$ & 2.25 & baik \\
& $\begin{array}{l}\text { jam } \\
250{ }^{\circ} \mathrm{C}, 5\end{array}$ & 2.2 & baik \\
j] & jam & & baik \\
& $250{ }^{\circ} \mathrm{C}, 4$ & 1.41 & baik \\
jam & & \\
\hline 5$]$ &
\end{tabular}

\section{Kesimpulan}

Dari studi literatur diatas dapat disimpulkan bahwa jenis adsorban akan memberikan pengaruh pada total asam yang dihasilkan. Perubahan bervariasi mulai dari $4.5 \%$ hingga $23,23 \%$. Penentuan jenis aktivator berpengaruh pada jumlah asam. Dimana aktivator garam menghasilkan jumlah asam lebih rendah daripada aktivator basa. Semakin panjang waktu pirolisis, semakin meningkat kandungan fenolnya. Sehingga kualitas dari asap cair dapat menjadi lebih baik. Suhu serta durasi pirolisis berpengaruh terhadap $\mathrm{pH}$ dari sebuah produk asap cair. Sehingga akan berdampak pada waktu simpan produk tersebut.

\section{Daftar Pustaka}

1. Tilgner, D.J. The Phenomena of Quality in the Smoke Curing Process; International Union of Pure and Applied Chemistry, 1978; Vol. 49;.

2. Doremire, M.E.; Harmon, G.E.; Pratt, D.E. 3,4-Benzopyrene in Charcoal Grilled Meats. Journal of Food Science 1979, 44, 622623.

3. Dewi, J.; Gani, A.; Nazar, M. Analisis Kualitas Asap Cair Tempurung Kelapa Dan Ampas Tebu Sebagai Bahan Pengawet Alami Pada Tahu. Jurnal IPA \& Pembelajaran IPA 2019, 2, 106-112, doi:10.24815/jipi.v2i2.12743.

4. Horri, M.; Eriawan, R.; Anggraini, S.P.A.; Yuniningsih, S. Teknologi Pengawetan 
Bahan Pangan Dengan Penambahan Asap Cair Dari Tempurung Kelapa Dan Sabut Kelapa Melalui Proses Pirolisis Dan Redestilasi | Horri | EUREKA: Jurnal Penelitian Teknik Sipil Dan Teknik Kimia. eUREKA: Jurnal Penelitian Mahasiswa Teknik Sipil dan Teknik Kimia 2018, 2, 9-18.

5. Tiya nurhazisa, Nicodemus susilo, S.S.N. Analisis Kandungan Benzo ( A ) Pyrene Terhadap Asap Cair Dari Tempurung Kelapa Dan Tongkol Jagung. 2018, 2, $193-$ 201.

6. Reta, K.B.; Anggraini, S.P.A. Pembuatan Asap Cair Dari Tempurung Kelapa, Tongkol Jagung, Dan Bambu Menggunakan Proses Slow Pyrolysis. Jurnal Reka Buana 2016, 1, 57-64.

7. Sansaka, fajar H. Rancang Bangun Asap Cair Dari Tongkol Jagung Menggunakan Proses Pyrolysis. 2013.

8. Fauziati, F.; Sampepana, E. Karakterisasi Komponen Aktif Asap Cair Cangkang Sawit Hasil Pemurnian. Jurnal Riset Teknologi Industri 2016, 9, 64-72, doi:10.26578/jrti.v9i1.1705.

9. Rinaldi, A.; Alimuddin; Panggabean, aman S. Pemurnian Asap Cair Dari Kulit Durian Dengan Menggunakan Arang Aktif. Journal of the Japanese Society of Pediatric Surgeons 2015, 4, 112-120, doi:10.11164/jjsps.4.1_156_2.

10. Nurhayati, T. Sifat Destilat Hasil Destilasi Kering 4 Jenis Kayu Dan Kemungkinan Pemanfaatannya Sebagai Pestisida. Buletin Penelitian Hasil Hutan 2000, 17, 160-168.

11. La ode indo, rahmanpiu, H. Pengaruh Pengunaan Adsorben Pasir Kuarsa Terhadap Sifat Fisiko Kimia Asap Cair Hasil Pirolisis Tempurung Kelapa 2019.

12. Oktafany, E.; Idiawati, N.; Harlia Pengaruh Destilasi Berulang Dan Pemurnian Menggunakan Zeolit Teraktivasi H2SO4 Terhadap Komposisi Asap Cair Tandan Kosong Kelapa Sawit (TKKS). Jurnal Kimia dan Kemasan (JKK) 2016, 5, 62-67.

13. Muflihati, I. Penurunan Smoky Flavor Dan Intensitas Warna Asap Cair Melalui Adsorpsi Bertingkat Menggunakan Arang Aktif Dari Sekam Padi. Jurnal Ilmiah Teknosains 2016, 2, 50-55.
14. Septi andini, M. Parameter Utama Asap Cair Untuk Standar Nasional Indonesia 2015.

15. Andriani, Y.; Mohamad, H.; Kassim, M.N.I.; Rosnan, N.D.; Syamsumir, D.F.; Saidin, J.; Muhammad, T.S.T.; Amir, H. Evaluation on Hydnophytum Formicarum Tuber from Setiu Wetland (Malaysia) and Muara Rupit (Indonesia) for Antibacterial and Antioxidant Activities, and Anti-Cancer Potency against MCF-7 and HeLa Cells. Journal of Applied Pharmaceutical Science 2017, 7, 30 37, doi:10.7324/JAPS.2017.70904.

16. Dewi, M. kusuma; Ratnasari, E.; Trimulyono, G. Aktivitas Antibakteri Ekstrak Daun Majapahit (Crescentia Cujete) Terhadap Pertumbuhan Bakteri Ralstonia Solanacearum Penyebab Penyakit Layu. Jurnal Lentera Bio 2014, 3, 51-57.

17. Zakki, M. Uji Aktivitas Antibakteri Ekstrak Cathechin Teh Putih Terhadap Streptococcus Sanguinis. ODONTO: Dental Journal 2017, 4, 108, doi:10.30659/odj.4.2.108-113.

18. Andriani, Y.; Mohamad, H.; Bhubalan, K.; Abdullah, M.I.; Amir, H. Phytochemical Analyses, Anti-Bacterial and Anti-Biofilm Activities of Mangrove-Associated Hibiscus Tiliaceus Extracts and Fractions against Pseudomonas Aeruginosa. Journal of Sustainability Science and Management 2017, 12, 45-51.

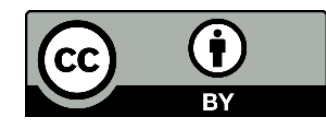

(C) 2021 by the authors. Licensee Fullerene Journal Of Chem. This article is an open access article distributed under the terms and conditions of the Creative Commons Attribution (CC BY) license (http://creativecommons.org/licenses/by/4.0/). 